\title{
PNEUMOTHORAX AND PNEUMOMEDIASTINUM AS A RARE COMPLICATION OF LAPAROSCOPIC SURGERY
}

\author{
Ivica Mamić ${ }^{1}$, Damir Danolić ${ }^{1}$, Mario Puljiz ${ }^{1}$, Miro Kasum², Ilija Alvir ${ }^{1}$, Lucija Kostić ${ }^{1}$, \\ Ivan Milas ${ }^{3}$, Andrea Ššštar ${ }^{4}$, Ivo Pedišićs ${ }^{5}$ and Tomislav Bečejac ${ }^{6}$ \\ ${ }^{1}$ Clinical Department of Gynecologic Oncology, University Hospital for Tumors, \\ Sestre milosrdnice University Hospital Center; ${ }^{2}$ Clinical Department of Obstetrics and Gynecology, \\ School of Medicine, Zagreb University Hospital Center; ${ }^{3}$ Clinical Department of Surgery, \\ ${ }^{4}$ Department of Anesthesiology, ${ }^{5}$ Department of Radiology, Sestre milosrdnice University Hospital Center; \\ Jordanovac Clinical Department of Thoracic Surgery, Zagreb University Hospital Center, Zagreb, Croatia
}

SUMMARY - Occurrence of bilateral pneumothorax, pneumomediastinum and subcutaneous emphysema during gynecologic laparoscopic procedure is very rare. We report a case of a 23 -year-old woman who developed bilateral pneumothorax, pneumomediastinum and subcutaneous emphysema during laparoscopic ovarian cystectomy. Carbon dioxide extravasations outside the peritoneal cavity during laparoscopy may have fatal consequences. Careful monitoring, immediate diagnosis and proper treatment are crucial for patient safety.

Key words: Laparoscopy - complications; Mediastinal emphysema; Pneumothorax; Subcutaneous emphysema; Case reports

\section{Introduction}

Laparoscopic management of adnexal masses is one of the most common gynecologic procedures. Lower mortality and morbidity, reduced postoperative pain, improved postoperative recovery and reduced costs have led to widespread use of this technique. In spite of its advantages, the method may have complications. Some of them are bowel injuries, vascular injuries, air embolism, cardiac arrhythmia, abdominal wall and omental vascular injuries, bladder and ureteral injuries ${ }^{1,2}$. Development of bilateral pneumothorax during laparoscopic procedure is a very rare but potentially life-threatening complication. The first case was described in $1939^{3}$. We present a case of bilat-

Correspondence to: Damir Danolić, MD, Clinical Department of Gynecologic Oncology, University Hospital for Tumors, Sestre milosrdnice University Hospital Center, Ilica 197, HR-10000 Zagreb, Croatia

E-mail: damir.danolic@gmail.com

Received September 3, 2015, accepted June 30, 2016 eral pneumothorax, pneumomediastinum and subcutaneous emphysema following laparoscopic ovarian cystectomy in a patient with recurrent ovarian mature teratoma.

\section{Case Report}

A 23-year-old nulliparous woman was admitted to our department for laparoscopic right ovarian cystectomy. She had no history of any pulmonary disease. Three years earlier, she was also admitted to our department because of intermittent lower abdominal pain and bilateral ovarian cysts. At that time, ultrasonography revealed a complex right ovarian cyst of approximately $4.1 \times 3.7 \mathrm{~cm}$ in size and mostly echogenic left ovarian cyst of approximately $2.5 \times 3.7 \mathrm{~cm}$ in size. Carbohydrate antigen 19-9 was elevated to $49.9 \mathrm{U} /$ $\mathrm{mL}$. Other tumor markers were within the normal limits. Laparoscopy was indicated and during induction of anesthesia the patient developed allergic reac- 
tion. Subsequent testing showed positive reaction to atropine, Dormicum, Esmeron, Lysthenon, Norcuron and Rapifen. Several weeks later, she underwent laparoscopically assisted left and right ovarian cystectomy and bilateral mature cystic teratomas were diagnosed histologically. Surgery and postoperative period passed without any complications. She received regular follow up care with periodic ultrasonography.

Three years after primary surgery, transvaginal ultrasonography examination revealed a multilocular right ovarian cyst of approximately $4.9 \times 4.0 \mathrm{~cm}$ in size. No ascites was detected. All tumor markers were within the normal range. Due to the presence of complex ovarian cyst, the patient underwent laparoscopy. After induction of anesthesia, carbon dioxide $\left(\mathrm{CO}_{2}\right)$ pneumoperitoneum was created using Veress needle insertion technique. Veress needle was inserted in the umbilical area in first attempt, with lifting the anterior abdominal wall. Initial intraperitoneal pressure was 1 $\mathrm{mm} \mathrm{Hg}$. After insufflation of $3.5 \mathrm{~L}$ of $\mathrm{CO}_{2}$, intraperitoneal pressures increased to up to $15 \mathrm{~mm} \mathrm{Hg}$. The infraumbilical trocar and two other trocars were placed without any technical difficulties. Laparoscopy was performed in lithotomy position. The right ovarian cyst was excised, placed into a bag and removed through the skin incision. The left ovary was normal. An automatic insufflator maintained intraperitoneal pressure at $12-14 \mathrm{~mm} \mathrm{Hg}$. At the end of the surgery, 40 minutes after infraumbilical incision, the anesthesiologist noticed rapid fall in oxygen saturation from $97 \%$ to $78 \%$ accompanied with a fall in blood pressure to $90 / 60 \mathrm{~mm} \mathrm{Hg}$ and rise in the heart rate to $120 /$ minute. Skin rash on the chest, cervical and facial subcutaneous emphysema were also present. Keeping in mind the differential diagnosis of allergic reaction, the patient received emergency treatment for anaphylactic reaction, but oxygen saturation did not improve. Clinical examination revealed a hyperresonance and decreased air entry on the left side of the chest. Chest xray revealed partial pneumothorax on the right side and complete pneumothorax on the left side, pneumomediastinum and subcutaneous emphysema (Fig. 1). Intercostal drain was placed in the fourth intercostal space in the left midaxillary line. After confirming adequate lung expansion on chest $\mathrm{x}$-ray, the patient was transferred to the Intensive Care Unit. Intercostal drain was removed on postoperative day 6 after confirming fully expanded both lungs with no pneumo-

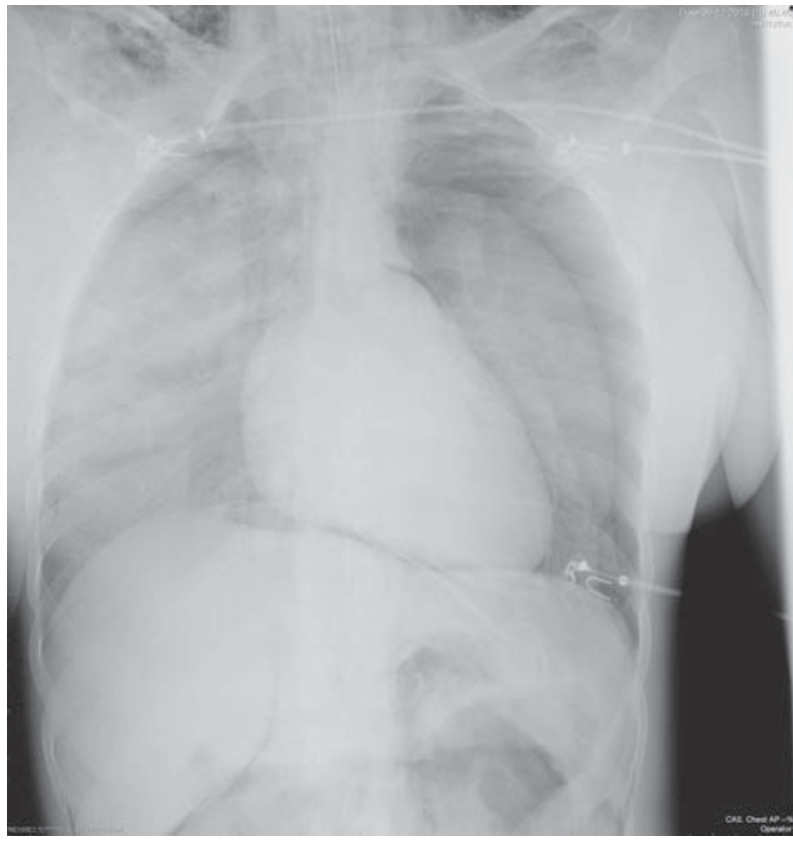

Fig. 1. Chest $x$-ray shows bilateral pneumothorax with partial collapse of the right lung and complete collapse of the left lung, a small amount of pneumomediastinum and bilateral supraand infraclavicular subcutaneous emphysema.

thorax. Further postoperative period was uneventful and the patient was discharged from the hospital to home care on postoperative day 7. Subsequently, histopathologic findings confirmed the diagnosis of mature cystic teratoma.

\section{Discussion}

Laparoscopy is a safe and effective procedure with a reported mortality rate between 3 and 8 deaths per 100,000 cases $^{1,4}$. Chapron et al. ${ }^{1}$ report an overall complication rate of 4.64 per 1000 gynecologic laparoscopies. Extremely uncommon complications consequential to gas insufflation are pneumothorax with a reported incidence of $0.03 \%$, pneumomediastinum with a reported incidence of $0.02 \%$, and clinically significant subcutaneous emphysema with a reported incidence of $0.43 \%$ to $2.34 \% \%^{5,6}$. The actual incidence of these complications might be significantly higher because many of them can go unrecognized ${ }^{7}$.

Asymptomatic subcutaneous emphysema is not uncommon. McAlister et al. performed routine postoperative computed tomography scan within $24 \mathrm{~h}$ of 
laparoscopic surgery and report grossly undetectable or clinical subcutaneous emphysema in $56 \%$ of cases $^{8}$. This condition, caused by leakage of $\mathrm{CO}_{2}$ around the trocar sites into the subcutaneous tissue, usually resolves spontaneously requiring conservative treatment with oxygen inhalation ${ }^{7}$. The clinical significance of subcutaneous emphysema is development of hypercarbia due to increased continuous $\mathrm{CO}_{2}$ absorption through large absorption surface area in the subcutaneous tissue 6 . The patients that develop massive subcutaneous emphysema should be carefully observed postoperatively. The possibility of coexisting pneumothorax and/or pneumomediastinum should also be kept in $\operatorname{mind}^{7}$.

Pneumomediastinum alone does not have any major clinical consequences. Richard et al. studied the significance of extra alveolar collections of air after laparoscopy and found that pneumomediastinum with or without pneumothorax was not associated with significant morbidity ${ }^{5}$. Routine postoperative care is appropriate for asymptomatic hemodynamically stable patients with isolated pneumomediastinum and appropriate oxygen saturation'. Extremely rare large amount of mediastinal air can lead to cardiorespiratory distress due to obstruction of normal return of venous blood to the heart ${ }^{9}$.

Pneumothorax during laparoscopy is a rare but lifethreatening complication. Gas accumulated in the pleural cavity can cause mild or severe pleural chest pain that usually resolves within $24 \mathrm{~h}$ even though pneumothorax still exists ${ }^{10}$. The results of physical examination in patients with pneumothorax may be normal or may include decreased chest wall movement on the affected side, unequal breath sounds and increased resonance on percussion ${ }^{10}$. Although these symptoms and signs are usually present, small pneumothorax in a healthy patient can go undetected. Pneumothorax should be suspected even in the absence of physical signs when there is a fall in blood pressure and oxygen saturation, an increase in the airway pressures and in the end-tidal $\mathrm{CO}_{2}$, or when unexplained hypoxia, hypercarbia, or hemodynamic instability occurs ${ }^{11}$. A high degree of suspicion is warranted for early diagnosis, proper treatment and prevention of lethal consequences. The risk factors for the development of pneumothorax or pneumomediastinum during laparoscopic surgery are older patient age, operating time of 200 minutes or more, higher maximum measured end-tid- al $\mathrm{CO}_{2}$ (>50 $\mathrm{mm} \mathrm{Hg}$ ), operator inexperience, operations such as fundoplasty or hiatal dissection, and the use of six or more surgical ports ${ }^{12}$. The laparoscopic upper abdominal surgery is an independent risk factor for pneumothorax ${ }^{12}$. In the case presented, the patient did not have any risk factors.

It is difficult to determine the etiology of these complications. The rupture of emphysematous bullae during mechanical ventilation due to barotrauma, direct surgical injury to the diaphragm, defects of the diaphragm, or existence of diaphragmatic congenital channels and diaphragmatic congenital weak points are believed to influence the development of pneumomediastinum and subsequently pneumothorax ${ }^{13}$. Carbon dioxide may also pass retroperitoneally through anatomical pathways (aortic and esophageal hiatuses of the diaphragm) to the mediastinum, later rupturing into the pleural cavity ${ }^{2}$. In our case, iatrogenic damage to diaphragm was ruled out. Although the presence of congenital diaphragmatic defects is believed to be the most common cause of pneumothorax during laparoscopy, this could be excluded in the case presented since first laparoscopy had passed with no complications. The etiology often remains unknown.

There are only few reported cases of bilateral pneumothorax, pneumomediastinum and subcutaneous emphysema after gynecologic laparoscopy. Fedun et $a l .{ }^{14}$ report a case of tension pneumothorax, pneumomediastinum and subcutaneous emphysema after laparoscopic hysterectomy, while Mekaru et al..$^{15}$ describe delayed pneumothorax after laparoscopic ovarian cystectomy. Y VS et al..$^{16}$ also report a similar case of pneumothorax, pneumomediastinum and ocular emphysema, which occurred during diagnostic laparoscopy in an infertile patient.

In conclusion, anesthesiologists and gynecologists/ surgeons should always be aware of these complications during laparoscopic procedures. Immediate and proper treatment is crucial to prevent the possible lethal outcome.

\section{References}

1. Chapron C, Querleu D, Bruhat MA, Madelenat P, Fernandez $\mathrm{H}$, Pierre F, et al. Surgical complications of diagnostic and operative gynaecological laparoscopy: a series of 29,966 cases. Hum Reprod. 1998;13:867-72.

2. Veena Shah, Beena Butala, Beena Parikh, Raj Raval. Bilateral pneumothorax as a complication of laparoscopy - a case report. Indian J Anaesth. 2003;47:55-6. 
3. Prystowsky JB, Jericho BG, Epstein HM. Spontaneous bilateral pneumothorax - complication of laparoscopic cholecystectomy. Surgery. 1993;114:988-92.

4. Bongard F, Dubecz S, Klein S. Complications of therapeutic laparoscopy. Curr Probl Surg. 1994;31:857-924.

5. Richard HM 3 $3^{\text {rd }}$, Stancato-Pasik A, Salky BA, Mendelson DS. Pneumothorax and pneumomediastinum after laparoscopic surgery. Clin Imaging. 1997;21:337-9.

6. Ott DE. Subcutaneous emphysema - beyond the pneumoperitoneum. JSLS J Soc Laparoend. 2014;18:1-7. doi: 10.4293/108 680813X13693422520882

7. Santana A, Crausman RS, Dubin HG. Late onset of subcutaneous emphysema and hypercarbia following laparoscopic cholecystectomy. Chest. 1999;115:1468-71.

8. McAllister JD, D’Altorio RA, Snyder A. CT findings after uncomplicated percutaneous laparoscopic cholecystectomy. J Comput Assist Tomogr. 1991;15:770-2.

9. Madan AK, Likes M, Raafat A. Pneumomediastinum as a complication of preperitoneal laparoscopic herniorrhaphy. JSLS J Soc Laparoend. 2003;7:73-5.

10. Noppen M, De Keukeleire T. Pneumothorax. Respiration. 2008;76:121-7.
11. Kaushik R, Attri AK. Spontaneous pneumothorax - a rare complication of laparoscopic cholecystectomy. Indian J Surg. 2004;66:294-6.

12. Murdock CM, Wolff AJ, Van Geem T. Risk factors for hypercarbia, subcutaneous emphysema, pneumothorax, and pneumomediastinum during laparoscopy. Obstet Gynecol. 2000;95: 704-9.

13. Machairiotis N, Kougioumtzi I, Dryllis G, Katsikogiannis N, Katsikogianni F, Courcoutsakis N, et al. Laparoscopy induced pneumothorax. J Thorac Dis. 2014;6:404-6. doi: 10.3978/j. issn.2072-1439.2014.08.15.

14. Fedun S, Mateu P, Gratiae E, Gelisse E, Just B. An unusual case of tension pneumoperitoneum causing subcutaneous emphysema, tension pneumothorax and pneumomediastinum after laparoscopic hysterectomy. Ann Fr Anesth Reanim. 2013;32: 628-9. doi: 10.1016/j.annfar.2013.07.803.

15. Mekaru K, Yagi C, Uezato T, Masamoto H, Aoki Y. Delayed pneumothorax after laparoscopic ovarian cystectomy. Arch Gynecol Obstet. 2009;280:157-9. doi: 10.1007/s00404-0080866-2.

16. Y VS, Suresh YA, Sequeira TF. Laparoscopy-pneumothorax and ocular emphysema, a rare complication - a case report. J Clin Diagn Res. 2014;8:GD01-2. doi: 10.7860/JCDR/2014/ 5997.4300 .

\section{Sažetak \\ PNEUMOTORAKS I PNEUMOMEDIJASTINUM - RIJETKE KOMPLIKACIJE LAPAROSKOPSKE KIRURGIJE}

\section{Mamić, D. Danolić, M. Puljiz, M. Kasum, I. Alvir, L. Kostić, I. Milas, A. Šoštar, I. Pedišić i T. Bečejac}

Razvoj obostranog pneumotoraksa, pneumomedijastinuma i supkutanog emfizema je iznimno rijetka komplikacija laparoskopske ginekološke operacije. U ovom radu prikazujemo slučaj 23-godišnje bolesnice u koje se razvio obostrani pneumotoraks, pneumomedijastinum i supkutani emfizem tijekom laparoskopske ovarijske cistektomije. Posljedice nakupljanja ugljičnog dioksida izvan trbušne šupljine tijekom laparoskopskih zahvata mogu biti fatalne. Brza dijagnoza i odgovarajuće liječenje su ključni za povoljan ishod.

Ključne riječi: Laparoskopija - komplikacije; Pneumotoraks; Medijastinum, emfizem; Potkožni emfizem; Prikazi slučaja 